\title{
PENGARUH KEADILAN KOMPENSASI DAN KEPUASAN KOMPENSASI TERHADAP KINERJA KARYAWAN PADA UMKM PEMBUATAN PEMPEK PALEMBANG
}

\author{
Wita Farla \\ Fakultas Ekonomi Universitas Sriwijaya \\ Email: witafarla@unsri.ac.id \\ Yuliansyah M. Diah \\ Fakultas Ekonomi Universitas Sriwijaya \\ Email: yuliansyah_diah@gmail.com \\ Fera Widyanata \\ Fakultas Ekonomi Universitas Sriwijaya \\ Email: ferawidyanata@gmail.com
}

\begin{abstract}
ABSTRAK
Penelitian ini bertujuan untuk menjelaskan dan membuktikan pengaruh dari keadilan kompensasi dan kepuasan kompensasi baik secara parsial maupun secara simultan terhadap kinerja karyawan pada UMKM pembuatan pempek Palembang. Rancangan penelitian yang digunakan dalam penelitian ini adalah riset deskriptif kausalitas dan data yang digunakan merupakan data kuantitatif. Berdasarkan sumbernya, data dalam penelitian ini merupakan data primer yang didapatkan langsung dari responden. Data dikumpulkan dengan menggunakan kuesioner yang terlebih dahulu diuji kelayakannya dengan uji validitas dan uji reliabilitas. Populasi dalam penelitian ini adalah karyawan yang bekerja pada UMKM pembuatan pempek Palembang, baik karyawan bagian produksi maupun karyawan yang memasarkan produk pempek. Teknik pengambilan sampel dengan menggunakan Purposive Sampling. Banyaknya sampel yang digunakan sebanyak 100 orang karyawan. Data dianalisis dengan menggunakan analisis deskriptif dan analisis regresi linier berganda. Hasil yang didapat dari penelitian ini adalah: (1) keadilan kompensasi tidak berpengaruh terhadap kinerja karyawan, (2) kepuasan kompensasi berpengaruh signifikan terhadap kinerja karyawan, (3) terdapat pengaruh secara bersama-sama antara keadilan kompensasi dan kepuasan kompensasi terhadap kinerja karyawan.
\end{abstract}

Kata kunci: keadilan kompensasi, kepuasan kompensasi, kinerja karyawan

\section{PENDAHULUAN}

Usaha Mikro, Kecil, dan Menengah (UMKM) merupakan penopang perekonomian Indonesia dan penyerap tenaga kerja yang cukup signifikan. Sebagian besar UMKM mampu bertahan dalam krisis ekonomi, hal ini antara lain karena penggunaan bahan baku, tenaga kerja, dan orientasi pasar yang bersifat lokal. Jumlah UMKM semakin bertambah banyak, meskipun demikian sebagian besar UMKM mengalami kesulitan dalam mengembangkan usahanya. Secara umum, persoalan yang dihadapi oleh UMKM meliputi aspek permodalan, pemasaran, kualitas tenaga kerja, dan organisasi kelembagaan.

$$
\text { Di Kota Palembang terdapat }
$$
36.100 UMKM dengan berbagai macam variasi usaha seperti usaha makanan, kerajinan tangan, furnitur, dan lain sebagainya. Di industri makanan terdapat 10 persen UMKM yang mengalami kebangkrutan. Hal ini disebabkan karena banyaknya persaingan dan turunnya daya beli masyarakat (http://www.palembang.go.id, 9 Agustus 2017). Meskipun demikian daya serap 
tenaga kerja untuk UMKM di Kota Palembang sangat besar. Terdapat 18.876 tenaga kerja untuk usaha mikro, 86.224 tenaga kerja untuk usaha kecil, dan 21.838 tenaga kerja untuk usaha menengah (http://palembang.tribunnews.com/, 11 April 2014).

UMKM sektor pangan di Kota Palembang terdiri dari UMKM pempek, kerupuk kemplang, dan makanan khas Palembang lainnya. Dari ketiga jenis UMKM pangan ini, pempek merupakan UMKM paling banyak di Kota Palembang, yaitu sebesar 45 persen (Welta, 2016). Pempek Palembang telah menembus pasar ASEAN sejak tahun 2013 dengan volume mencapai 8 ton per bulan dan sudah menjadi salah satu dari 17 jenis komoditas unggulan ekspor nonmigas Provinsi Sumatera Selatan (Heri Setiawan, 2017). Sebagai makanan khas, pempek dijadikan sebagai oleh-oleh atau buah tangan, selain itu terdapat budaya makan pempek bagi masyarakat Palembang sehingga usaha pembuatan pempek tersebar dibanyak tempat di Kota Palembang dengan berbagai nama dagang (Nurfitriana, Fatchiya, \& Susanto, 2016; Muljanah, 2009).

UMKM yang tidak mampu bersaing akan mengalami kerugian secara terus-menerus dan akhirnya akan mengalami kebangkrutan. Salah satu penyebab lemahnya daya saing UMKM adalah dari sisi kinerja karyawan yang dipekerjakan (Fernanda \& Sagoro, 2016). Karyawan yang kurang terampil, tidak termotivasi dalam bekerja, ataupun karyawan yang merasa tidak puas terhadap pekerjaannya adalah sebagian masalah yang dihadapi oleh perusahaan.

Kepuasan karyawan dapat disebabkan oleh beberapa hal, diantaranya adalah kepuasan terhadap kompensasi yang mereka terima. Kompensasi dapat berupa gaji dan tunjangan serta fasilitasfasilitas kerja lainnya. Seorang karyawan akan membandingkan kompensasi yang didapatnya dengan rekan kerjanya maupun dengan karyawan pada perusahaan lainnya. Pada saat karyawan membandingkan kompensasi yang didapatnya, mereka akan menilai apakah kompensasi yang mereka terima sudah memenuhi prinsip keadilan atau belum.

Industri pembuatan pempek menggunakan cukup banyak karyawan, mulai dari karyawan bagian produksi sampai karyawan bagian penjualan. Dengan banyaknya karyawan disetiap usaha pempek, maka dapat terjadi rasa ketidakadilan dalam pemberian kompensasi baik diantara karyawan dalam satu usaha pempek maupun antar karyawan pada usaha pempek yang berbeda.

Banyak penelitian yang membahas tentang pengaruh kompensasi terhadap kepuasan kerja dan kinerja karyawan (Fernanda \& Sagoro, 2016),(Tamma \& Iskandar, 2015) dan (Sadzwina \& Gilang, 2015), namun belum banyak yang membahas mengenai keadilan dalam kompensasi dan kepuasan terhadap kompensasi itu sendiri. Kepuasaan terhadap kompensasi dapat disebabkan oleh keadilan dalam kompensasi tersebut, jadi keadilan kompensasi berhubungan erat dengan kepuasaan kompensasi (Jackson, Schuler, \& Werner, 2011). Hasil penelitian (Intan Retno Edy, 2013) menemukan bahwa keadilan kompensasi akan mempengaruhi kepuasan kerja, tapi tidak mempengaruhi kinerja karyawan sementara itu hasil penelitian (Muljani, Pengajar, Ekonomi, Katolik, \& Surabaya, 2002) menemukan bahwa keadilan 
kompensasi akan meningkatkan kinerja karyawan.

Melihat masih terjadinya inkonsistensi dari beberapa hasil penelitian tentang pengaruh keadilan kompensasi terhadap kepuasan kompensasi dan kinerja karyawan, maka dirasakan perlu untuk melakukan penelitian kembali mengenai topik ini.

\section{TINJAUAN TEORI}

\section{Pengertian Kompensasi}

Kompensasi merupakan salah satu fungsi dari Manajemen Sumber Daya Manusia (SDM). Menurut (Dessler, 2017) kompensasi merupakan semua bentuk bayaran yang diberikan kepada karyawan dan timbul dari hubungan kerja mereka. Sedangakan menurut (Hasibuan, 2011) kompensasi adalah semua pendapatan yang berbentuk uang, barang langsung atau tidak langsung yang diterima karyawan sebagai imbalan atas jasa yang diberikan kepada perusahaan. Tujuan pemberian kompensasi, antara lain untuk: ikatan kerja sama, kepuasan kerja, motivasi, dan pengadaan efektif karyawan.

Komponen dari kompensasi karyawan terdiri dari kompensasi finansial langsung dan kompensasi finansial tidak langsung (Dessler, 2017). Kompensasi finansial langsung, berupa: bayaran pokok (gaji dan upah), bayaran prestasi, bayaran insentif (bonus, komisi, pembagian laba dan opsi saham), dan bayaran tertangguh (program tabungan dan anuitas pembelian saham) sedangkan kompensasi finansial tidak langsung dapat berupa: programprogram proteksi (asuransi kesehatan, asuransi jiwa, asuransi tenaga kerja, pensiun), bayaran diluar jam kerja (liburan, hari besar, cuti tahunan, dan cuti hamil) dan fasilitas-fasilitas lainnya seperti kendaran dan ruang kantor.
Menurut (Hasibuan, 2011), program kompensasi yang ditetapkan harus memenuhi prinsip adil dan layak supaya kompensasi yang diberikan dapat merangsang kepuasan dan kinerja karyawan. Menurut asas adil, besarnya kompensasi yang dibayar kepada setiap karyawan harus disesuaikan dengan prestasi kerja, jenis pekerjaan, risiko pekerjaan, tanggungjawab, jabatan pekerja, dan memenuhi persyaratan internal konsistensi, jadi dalam hal ini setiap karyawan tidak menerima kompensasi yang sama besarnya. Berdasarkan asas layak, kompensasi yang diterima karyawan dapat memenuhi kebutuhannya pada tingkat normatif yang ideal. Tolak ukur layak adalah relatif, penetapan besarnya kompensasi didasarkan atas batas upah minimal pemerintah dan eksternal konsistensi yang berlaku.

\section{Keadilan dalam Kompensasi}

Salah satu asas dalam kompensasi adalah asas keadilan. Teori keadilan dikemukakan oleh Adam pada tahun 1963, mengungkapkan bahwa orang akan merasa puas atau tidak puas tergantung pada ada atau tidaknya keadilan dalam suatu situasi, khususnya situasi kerja. Teori keadilan lebih jauh menyatakan bahwa seseorang termotivasi terhadap persepsi keadilan atas imbalan yang diterima untuk usaha tertentu dibandingkan dengan apa yang diterima orang lain (Mondy R.W., 2016)

Menurut (Jackson et al., 2011) keadilan pembayaran adalah apa yang dirasa pantas oleh pegawai untuk mereka dapatkan sama dengan apa yang orang lain pantas dapatkan. Keadilan pembayaran akan berhubungan erat dengan kepuasan pembayaran. Ketika membandingkan keadilan kompensasi, karyawan akan 
membandingkan rasio masukan dan hasil mereka dengan masukan dan hasil orang lain. Masukan (input) seorang karyawan dapat berupa waktu, usaha, pengalaman, dan tingkat pendidikan. Sedangkan hasil (output) dapat berupa gaji, tunjangan, dan rasa keberartian.

Sementara itu (Mondy R.W., 2016) menyatakan bahwa keadilan finansial diartikan sebagai persepsi perlakuan pembayaran yang adil bagi para karyawan. Keadilan finansial ini dilihat berdasarkan keadilan eksternal dan keadilan internal. Keadilan eksternal terwujud ketika karyawan sebuah perusahaan menerima bayaran yang sebanding dengan karyawan yang melakukan pekerjaan yang serupa di perusahaan lain sedangkan keadilan internal terwujud ketika karyawan menerima bayaran menurut nilai relatif pekerjaannya dalam organisasi yang sama.

\section{Kepuasan Kompensasi}

Kepuasan terhadap kompensasi yang diterima oleh karyawan merupakan salah satu dimensi dari kepuasan kerja (Robbins \& Judge, 2013). Menurut (Jackson et al., 2011) kepuasan kompensasi merupakan jumlah perasaan positif atau negatif yang dirasakan oleh karyawan terhadap gaji mereka, dimana karyawan akan melihat apakah kompensasi yang diterima sudah sesuai dengan yang mereka harapkan. Kepuasan terhadap kompensasi dibentuk oleh beberapa dimensi, yaitu: kepuasan terhadap tingkat gaji (pay level), kepuasan terhadap berbagai jenis tunjangan yang ada (benefits), kepuasan terhadap kenaikan gaji (pay raise), dan kepuasan terhadap

\section{Kerangka Pemikiran}

Berdasarkan tinjauan pustaka diatas, dapat dibuat suatu kerangka berpikir sebagai berikut: administrasi penggajian (pay administration). Salah satu alat untuk mengukur kepuasan terhadap kompensasi adalah dengan menggunakan Pay Satisfaction Questionnaire (PSQ). PSQ merupakan sebuah daftar pertanyaan yang ditujukan untuk menilai kepuasan kerja terhadap aspek pembayaran.

\section{Kinerja Karyawan}

Menurut (Mangkunegara, 2003) kinerja karyawan merupakan hasil yang diperoleh oleh seseorang dalam melaksanakan tugas pekerjaan yang dibebankan kepadanya. Sedangkan menurut Menurut (Hasibuan, 2011), kinerja karyawan adalah suatu hasil kerja yang dicapai seseorang dalam melaksanakan tugas-tugas yang dibebankan kepadanya yang didasarkan atas kecakapan, pengalaman, dan kesungguhan serta waktu. Kinerja karyawan merupakan gabungan dari tiga faktor penting, yaitu kemampuan dan minat karyawan, kemampuan dan penerimaan atas penjelasan delegasi tugas, serta peran dan tingkat motivasi seorang karyawan.

Terdapat lima dimensi dari kinerja karyawan, meliputi: kuantitas, kualitas, waktu penyelesaian, tingkat kehadiran, dan komunikasi (Mathis \& Jackson, 2010). Sementara itu menurut (Robbins \& Judge, 2013) terdapat enam dimensi yang dapat digunakan untuk mengukur kinerja seorang karyawan, yaitu: kuantitas kerja, kualitas kerja, ketepatan waktu kerja, efektivitas, tingkat kemandirian, dan hubungan interpersonal. 


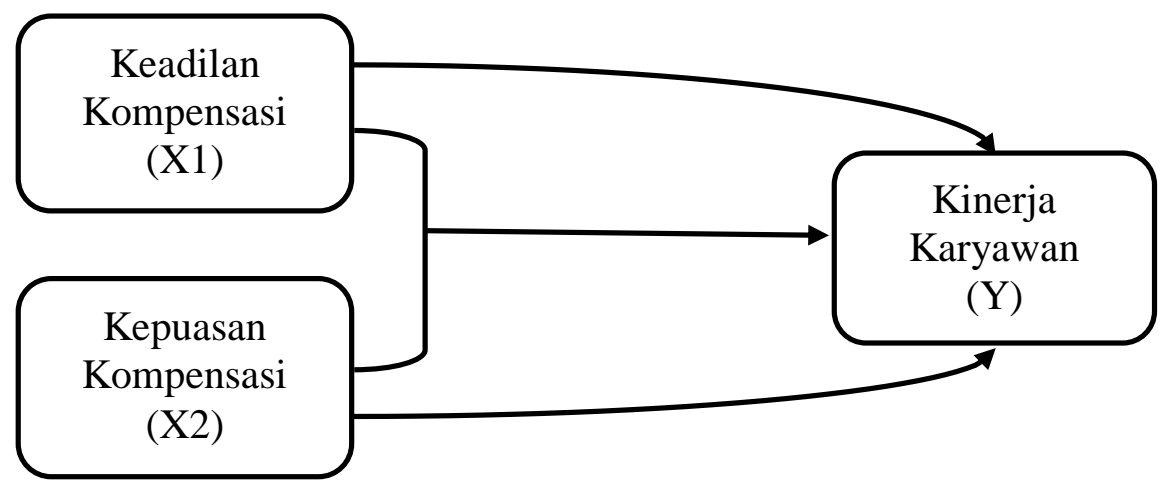

\section{Gambar 1. Kerangka Pemikiran}

\section{METODE PENELITIAN}

\section{Rancangan Penelitian}

Rancangan penelitian yang digunakan dalam penelitian ini adalah riset deskriptif kausalitas yang bertujuan untuk mengetahui pengaruh dari variabel bebas terhadap variabel terikatnya.

\section{Jenis dan Sumber Data}

Data yang digunakan dalam penelitian ini merupakan data kuantitatif. Data ini berbentuk angka atau dijadikan angka. Berdasarkan sumbernya, data dalam penelitian ini merupakan data primer yang didapatkan langsung dari responden.

\section{Teknik Pengumpulan Data}

Data dikumpulkan dengan menggunakan angket atau kuesioner. Angket ini berisi sejumlah daftar pertanyaan yang berhubungan dengan masalah penelitian, yang akan diisi oleh responden. Angket ini sebelum disebarkan kepada responden terlebih dahulu diuji kelayakannya dengan uji validitas dan uji reliabilitas.

\section{Populasi dan Sampel}

Populasi dalam penelitian ini adalah karyawan yang bekerja pada
UMKM pembuatan pempek Palembang, baik karyawan bagian produksi maupun karyawan yang memasarkan produk pempek. Teknik pengambilan sampel dengan menggunakan Purposive Sampling. Hampir disetiap tempat di Kota Palembang terdapat usaha pembuatan pempek, namun pada penelitian ini daerah yang akan dijadikan sampel penelitian adalah daerah-daerah yang menjadi sentra penghasil pempek, yaitu daerah 26 Ilir, Seberang Ulu I, dan Seberang Ulu II. Banyaknya sampel yang akan digunakan sebanyak 100 orang karyawan yang bekerja diusaha pembuatan pempek.

\section{Teknik Analisis}

Teknik analisis yang digunakan pada penelitian ini adalah analisis deskriptif dan analisis regresi linier berganda dengan pengolahan data menggunakan Program SPSS.

1. Analisis Deskriptif

Teknik ini digunakan untuk mendeskripsikan atau menggambarkan data yang telah dikumpulkan. Analisis deskriptif dilakukan dengan menggunakan distribusi frekuensi untuk menyusun data yang jumlahnya relatif banyak kedalam suatu tabel frekuensi sehingga memudahkan dalam 
membaca data dan memahami maksudnya.

2. Analisis Regresi Linier Berganda Teknik ini digunakan untuk melihat ada tidaknya pengaruh dari variabel bebas terhadap variabel terikatnya.

\section{Definisi Operasional Variabel}

Untuk mengukur variabel dalam penelitian ini digunakan definisi operasional sebagai berikut:

1. Keadilan kompensasi adalah persepsi perlakuan pembayaran yang adil bagi para karyawan. Dimensi dari keadilan kompensasi adalah keadilan eksternal dan keadilan internal. Keadilan eksternal terwujud ketika karyawan menerima bayaran yang sebanding dengan karyawan yang melakukan pekerjaan serupa di perusahaan lain sedangkan keadilan internal terwujud ketika karyawan menerima bayaran menurut nilai relatif pekerjaannya dalam organisasi yang sama (Mondy R.W., 2016).

2. Kepuasan kompensasi adalah sejumlah perasaan positif atau negatif yang dirasakan oleh karyawan terhadap gaji mereka. Kepuasan terhadap kompensasi dibentuk oleh beberapa dimensi, yaitu: kepuasan terhadap tingkat gaji, kepuasan terhadap berbagai jenis tunjangan yang ada, kepuasan terhadap kenaikan gaji, dan kepuasan terhadap administrasi penggajian (Jackson et al., 2011).

3. Kinerja karyawan adalah hasil yang diperoleh oleh seorang karyawan dalam melaksanakan pekerjaannya. Dimensi yang digunakan untuk mengukur kinerja karyawan, yaitu : kuantitas, kualitas, ketepatan waktu, kehadiran, komunikasi (Mathis \& Jackson, 2010).

\section{HASIL DAN PEMBAHASAN}

\section{Uji Validitas dan Reliabilitas}

Uji validitas dilakukan dengan melihat nilai Corrected Item Total Correlation (CITC). Jika nilai CITC lebih besar dari nilai $\mathrm{r}$ tabel, maka dikatakan valid sedangkan uji reliabilitas dilakukan dengan melihat nilai Cronbach's Alpha, jika nilai Cronbach's Alpha diatas 0,7 maka dikatakan baik/reliable.

Tabel 1. Hasil Uji Validitas dan Reliabiltas Variabel Keadilan Kompensasi

\begin{tabular}{|c|c|c|c|c|}
\hline \multirow{8}{*}{ Uji Validitas } & Indikator & CITC & r tabel & Keterangan \\
\hline & Keadilan kompensasi 1 & 0,473 & 0,17 & Valid \\
\hline & Keadilan kompensasi 2 & 0,497 & & Valid \\
\hline & Keadilan kompensasi 3 & 0,232 & & Valid \\
\hline & Keadilan kompensasi 4 & 0,505 & & Valid \\
\hline & Keadilan kompensasi 5 & 0,417 & & Valid \\
\hline & Keadilan kompensasi 6 & 0,544 & & Valid \\
\hline & Keadilan kompensasi 7 & 0,288 & & Valid \\
\hline \multirow[t]{2}{*}{ Uji Reliabilitas } & \multicolumn{2}{|c|}{ Cronbach's Alpha } & $\begin{array}{l}\text { Standar } \\
\text { reliabilitas }\end{array}$ & Keterangan \\
\hline & \multicolumn{2}{|l|}{0,720} & 0,700 & Baik \\
\hline
\end{tabular}

Sumber: Data primer diolah, 2018 
Hasil uji validitas pada tabel di atas menunjukkan semua indikator untuk variabel keadilan kompensasi dinyatakan valid karena nilai CITC dari masingmasing indikator tersebut lebih besar dari nilai $r$ tabel. Begitupula dengan hasil uji reliabilitas, terlihat bahwa nilai Cronbach's Alpha sebesar 0,720. Nilai ini lebih besar dari nilai standar reliabilitas 0,700 sehingga dapat dinyatakan bahwa indikator yang digunakan reliable atau baik.

Tabel 2. Hasil Uji Validitas dan Reliabiltas

\section{Variabel Kepuasan Kompensasi}

\begin{tabular}{ccccc}
\hline Uji Validitas & Indikator & CITC & r tabel & Keterangan \\
& Kepuasan kompensasi 1 & 0,348 & 0,17 & Valid \\
& Kepuasan kompensasi 2 & 0,343 & & Valid \\
& Kepuasan kompensasi 3 & 0,493 & & Valid \\
& Kepuasan kompensasi 4 & 0,525 & & Valid \\
& Kepuasan kompensasi 5 & 0,551 & & Valid \\
& Kepuasan kompensasi 6 & 0,622 & & Valid \\
& Kepuasan kompensasi 7 & 0,428 & & Valid \\
& Kepuasan kompensasi 8 & 0,496 & & Valid \\
& Kepuasan kompensasi 9 & 0,529 & & Valid \\
& Kepuasan kompensasi 10 & 0,392 & & Valid \\
& Kepuasan kompensasi 11 & 0,344 & & Valid \\
& Kepuasan kompensasi 12 & 0,259 & & Valid \\
& Kepuasan kompensasi 13 & 0,282 & & Valid \\
Cji Reliabilitas & Cronbach's Alpha & & Standar & Keterangan \\
& 0,801 & & 0,700 & Baik \\
\hline
\end{tabular}

Sumber: Data primer diolah, 2018

Hasil uji validitas pada tabel di atas menunjukkan semua indikator untuk variabel kepuasan kompensasi dinyatakan valid karena nilai CITC dari masingmasing indikator tersebut lebih besar dari nilai $r$ tabel. Begitupula dengan hasil uji reliabilitas, terlihat bahwa nilai Cronbach's Alpha sebesar 0,801. Nilai ini lebih besar dari nilai standar reliabilitas 0,700 sehingga dapat dinyatakan bahwa indikator yang digunakan reliable atau baik.

Tabel 3. Hasil Uji Validitas dan Reliabiltas

Variabel Kinerja

\begin{tabular}{ccccc}
\hline Uji Validitas & Indikator & CITC & r tabel & Keterangan \\
& Kinerja 1 & 0,219 & 0,17 & Valid \\
& Kinerja 2 & 0,246 & & Valid \\
& Kinerja 3 & 0,496 & & Valid \\
& Kinerja 4 & 0,484 & & Valid \\
& Kinerja 5 & 0,213 & & Valid \\
& Kinerja 6 & 0,290 & & Valid \\
& Kinerja 7 & 0,354 & & Valid \\
& Kinerja 8 & 0,104 & & Tidak Valid \\
& Kinerja 9 & 0,328 & Valid \\
& Kinerja 10 & 0,283 & Valid \\
\hline
\end{tabular}




\begin{tabular}{|c|c|c|c|c|}
\hline & Kinerja 11 & 0,325 & & Valid \\
\hline & Kinerja 12 & 0,372 & & Valid \\
\hline & Kinerja 13 & 0,322 & & Valid \\
\hline & Kinerja 14 & 0,288 & & Valid \\
\hline & Kinerja 15 & 0,409 & & Valid \\
\hline & Kinerja 16 & 0,429 & & Valid \\
\hline & Kinerja 17 & 0,369 & & Valid \\
\hline \multirow[t]{2}{*}{ Uji Reliabilitas } & \multicolumn{2}{|c|}{ Cronbach's Alpha } & $\begin{array}{c}\text { Standar } \\
\text { reliabilitas }\end{array}$ & Keterangan \\
\hline & \multicolumn{2}{|c|}{0,736} & 0,700 & Baik \\
\hline
\end{tabular}

Sumber: Data primer diolah, 2018

Tabel uji validitas dari variabel kinerja di atas menunjukkan ada satu indikator yang tidak valid, yaitu kinerja 8 sehingga indikator ini harus dibuang. Sementara itu, indikator-indikator lainnya dinyatakan valid karena nilai CITC dari masing-masing indikatot tersebut lebih besar dari nilai $r$ tabel. Begitupula dengan hasil uji reliabilitas, terlihat bahwa nilai Cronbach's Alpha sebesar 0,736. Nilai ini lebih besar dari nilai standar reliabilitas 0,700 sehingga dapat dinyatakan bahwa indikator yang digunakan reliable atau baik.

\section{Gambaran Karakteristik Responden Berdasarkan Jenis Kelamin Tabel 4. Jenis Kelamin Responden

\begin{tabular}{lc}
\hline \multicolumn{1}{c}{ Jenis Kelamin } & Jumlah \\
\hline Laki-laki & 32 \\
\hline Perempuan & 68 \\
\hline Total & 100 \\
\hline
\end{tabular} \\ Sumber: data primer diolah, 2018}

Berdasarkan tabel diatas, sebagian

besar responden berjenis kelamin perempuan, yaitu sebanyak 68 orang.

\section{Gambaran Karakteristik Responden Berdasarkan Usia}

Tabel 5. Usia Responden

\begin{tabular}{llc} 
& \multicolumn{1}{c}{ Kelompok usia } & Jumlah \\
\cline { 2 - 3 } & Kurang dari 20 tahun & 26 \\
\cline { 2 - 3 } $20-30$ tahun & 49 \\
\cline { 2 - 3 } 31-40 tahun & 20 \\
\cline { 2 - 3 } Sumber: data & Lebih dari 40 tahun & 5 \\
\cline { 2 - 3 } & Total & 100 \\
\cline { 2 - 3 }
\end{tabular}

Berdasarkan tabel diatas, sebagian besar responden berada pada kelompok usia 20 tahun sampai 30 tahun, sebanyak 49 orang.

\section{Gambaran Karakteristik Responden Berdasarkan Status Pernikahan}


Tabel 6. Status Pernikahan Responden

\begin{tabular}{|c|c|}
\hline Status Pernikahan & Jumlah \\
\hline Menikah & 43 \\
\hline Belum menikah & 54 \\
\hline Janda/duda) & 3 \\
\hline Total & 100 \\
\hline
\end{tabular}

Berdasarkan hasil pengolahan data primer, diketahui bahwa sebagian besar responden berstatus belum menikah, sebanyak 54 orang.

\section{Gambaran Karakteristik Responden Berdasarkan Pendidikan} Tabel 7. Tingkat Pendidikan Responden

\begin{tabular}{lc}
\hline \multicolumn{1}{c}{ Tingkat Pendidikan } & Jumlah \\
\hline Dibawah SMU/sederajat & 22 \\
\hline SMU/sederajat & 67 \\
\hline Perguruan tinggi & 11 \\
\hline Total & 100
\end{tabular}

Sumber: data primer diolah, 2018

Data diatas menunjukkan bahwa sebagian besar responden berpendidikan SMU/sederajat, yaitu sebanyak 67 orang.

\section{Gambaran Karakteristik Responden Berdasarkan Gaji}

Tabel 8. Gaji Responden

\begin{tabular}{lc}
\hline \multicolumn{1}{c}{ Besarnya Gaji } & Jumlah \\
\hline$<\operatorname{Rp~} 500.000$ & 12 \\
\hline $\operatorname{Rp} 500.000-\operatorname{Rp~} 1.500 .000$ & 63 \\
\hline $\operatorname{Rp~} 1.500 .000-\operatorname{Rp~} 2.500 .000$ & 23 \\
\hline$>\operatorname{Rp} 2.500 .000$ & 2 \\
\hline Total & 100
\end{tabular}

Sumber: data primer diolah, 2018

Data diatas menunjukkan bahwa

sebagian besar responden memiliki gaji dikisaran Rp 500.000 sampai Rp 1.500.000, yaitu sebanyak 63 orang.

Gambaran Karakteristik Responden Berdasarkan Masa Kerja Tabel 9. Masa Kerja Responden

\begin{tabular}{cc}
\hline Masa kerja & Jumlah \\
\hline$<1$ tahun & 36 \\
\hline
\end{tabular}




\begin{tabular}{lc}
\hline $1-5$ tahun & 55 \\
\hline $6-10$ tahun & 7 \\
\hline$>10$ tahun & 2 \\
\hline Total & 100
\end{tabular}

Sumber: data primer diolah, 2018

Tabel diatas menunjukkan bahwa responden paling banyak berada pada kelompok masa kerja 1 tahun sampai 5 tahun sebanyak 55 orang.

Hubungan Keadilan Kompensasi, Kepuasan Kompensasi dengan Kinerja Karyawan Tabel 10. Korelasi

\begin{tabular}{|l|l|r|r|r|}
\hline & & Kinerja & $\begin{array}{c}\text { Keadilan } \\
\text { Kompensasi }\end{array}$ & $\begin{array}{c}\text { Kepuasan } \\
\text { Kompensasi }\end{array}$ \\
\hline Pearson Correlation & Kinerja & 1.000 & .093 & .301 \\
& Keadilan Kompensasi & .093 & 1.000 & .450 \\
& Kepuasan Kompensasi & .301 & .450 & 1.000 \\
\hline Sig. (1-tailed) & Kinerja &. & .179 & .001 \\
& Keadilan Kompensasi & .179 &. & .000 \\
& Kepuasan Kompensasi & .001 & .000 &. \\
\hline
\end{tabular}

Sumber: data primer diolah, 2018

Tabel korelasi diatas menunjukkan bahwa hubungan antara keadilan kompensasi dengan kinerja karyawan sebesar 0,093 dengan signifikasi korelasi sebesar 0,179. Nilai signifikasi ini lebih besar dari batas kesalahan $(\alpha)$ sebesar 0,05 atau $0,179>0,05$ maka dapat dikatakan tidak ada hubungan antara keadilan kompensasi dengan kinerja karyawan.

Hubungan antara kepuasan kompensasi dengan kinerja karyawan sebesar 0,301 dengan signifikansi korelasi sebesar 0,001. Nilai signifikansi lebih kecil dari batas kesalahan $(\alpha)$ sebesar 0,05 atau $0,001<0,05$ maka maka dapat dikatakan ada hubungan antara kepuasan kompensasi dengan kinerja karyawan. Arah hubungan yang positif menunjukkan bahwa semakin tinggi kepuasan kompensasi karyawan, maka semakin baik kinerjanya.

\section{Pengaruh Kepuasan Kompensasi dan Keadilan Kompensasi Terhadap Kinerja}

Karyawan

Uji Koefisien Regresi Secara Bersama-sama (Uji F)

\begin{tabular}{cc}
\multicolumn{2}{c}{ Tabel 11. Uji F } \\
\cline { 2 - 2 } Keterangan & Nilai \\
\cline { 2 - 2 } Sig & 0,009 \\
\hline Sumbr: data primer diolah, 2018
\end{tabular}

Berdasarkan hasil perhitungan Uji

F diperoleh angka signifikansi sebesar
0,009. Jika signifikansi $<0,05$, artinya terdapat pengaruh antara variabel bebas 
dengan variabel terikat. Angka 0,009 < 0,05 sehingga dapat dikatakan model tersebut linier atau ada pengaruh secara bersama-sama antara variabel keadilan kompensasi dan kepuasan kompensasi terhadap kinerja karyawan.

\section{Uji Koefisien Regresi Secara Parsial (Uji t)}

Tabel 12. Uji t

\begin{tabular}{lcccc}
\hline \multirow{2}{*}{ Keterangan } & \multirow{2}{*}{ B } & Signifikan & \multicolumn{2}{c}{ Statistik Kolinearitas } \\
\cline { 4 - 5 } & & & Toleransi & VIF \\
\hline Konstan) & 55,583 & 0,000 & - & - \\
Keadilan kompensasi & $-0,077$ & 0,623 & 0,797 & 1,255 \\
Kepuasan kompensasi & 0,274 & 0,003 & 0,797 & 1,255
\end{tabular}

Sumber: data primer diolah, 2018

1. Pengaruh Keadilan Kompensasi terhadap Kinerja Karyawan

Berdasarkan tabel diatas, terlihat nilai signifikansi sebesar 0,623. Nilai ini lebih besar dari 0,05. Hal ini berarti variabel keadilan kompensasi tidak berpengaruh signifikan terhadap kinerja karyawan.

2. Pengaruh Kepuasan Kompensasi terhadap Kinerja Karyawan

Tabel diatas menunjukkan nilai signifikansi 0,003 yang lebih kecil dari 0,05. Hal ini berarti variabel kepuasan kompensasi berpengaruh signifikan terhadap kinerja karyawan.

3. Uji Multikolinearitas

Nilai toleransi dan nilai VIF adalah nilai yang menunjukkan ada atau tidaknya hubungan linier antara variabel bebas dalam sebuah model regresi. Jika nilai toleransi lebih kecil dari 0,1 dan nilai VIF lebih besar dari 10, maka dikatakan terjadi multikolinearitas. Tabel 12 di atas menunjukkan nilai tolerasi dan nilai VIF dari masing-masing variabel bebas lebih dari 0,1 dan kurang dari 10, sehingga dapat dikatakan bahwa tidak terjadi multikolinearitas.

\section{Analisis Persamaan Regresi Linier Berganda}

Nilai-nilai dari output koefisien regresi pada Tabel 12 dapat dimasukkan ke dalam persamaan regresi, sehingga persamaan regresinya adalah sebagai berikut:

$\mathrm{Y}=55,583-0,077 \mathrm{X}_{1}+0,274 \mathrm{X}_{2}$

\section{Pembahasan}

Berdasarkan

karakteristik

responden sebagian besar karyawan yang bekerja di UMKM pembuatan pempek berjenis kelamin perempuan dengan usia diantara 20 sampai 30 tahun dan tingkat pendidikan setara SMU. Karyawan yang bekerja di UMKM pembuatan pempek memerlukan keahlian bisa membuat pempek. Keahlian ini sebagian besar dimiliki oleh perempuan. Usia 20 sampai 30 tahun merupakan usia produktif untuk bekerja dan biasanya perempuan yang telah menyelesaikan pendidikan tingkat SMU dan tidak melanjutkan pendidikan akan memutuskan untuk bekerja.

Sebagian besar karyawan berstatus belum menikah, karena setelah menikah sebagian karyawan perempuan akan memutuskan untuk berhenti bekerja sehingga masa kerja mereka hanya 
berkisar satu sampai lima tahun. Penghasilan yang diterima karyawan sebesar Rp 500.000 sampai Rp 1.500.000. Penghasilan ini dirasakan relatif cukup untuk memenuhi kebutuhan bagi karyawan yang berstatus belum menikah.

Hasil analisis korelasi dan regresi menemukan bahwa keadilan kompensasi tidak memiliki hubungan dan tidak berpengaruh terhadap kinerja karyawan. Hal ini sejalan dengan hasil penelitian (Intan Retno Edy, 2013). Keadilan kompensasi dapat berupa keadilan internal maupun eksternal (Mondy \& J. Martocchio, 2016). Karyawan yang bekerja di UMKM pembuatan pempek rata-rata memiliki tingkat pendidikan dan keahlian yang sama sehingga bayaran yang mereka terima pun juga sama, begitupula ketika para karyawan membandingkan bayarannya dengan karyawan yang bekerja pada UMKM pembuatan pempek yang lain. Kompensasi karyawan UMKM pembuatan pempek hampir rata-rata sama sehingga variabel keadilan kompensai tidak berpengaruh pada kinerja karyawan.

Penelitian ini juga menemukan bahwa variabel kepuasan kompensasi memiliki hubungan dan berpengaruh signifikan terhadap kinerja karyawan. Hasil penelitian ini serupa dengan hasil penelitian (Siagian, 2015). Kepuasan kompensasi merupakan perasaan positif atau negatif yang dirasakan oleh karyawan terhadap gaji mereka, yang diukur berdasarkan tingkat gaji, tunjangan, kenaikan gaji, dan administrasi gaji (Jackson et al., 2011). Jika karyawan merasa puas terhadap kompensasi total mereka yang berupa gaji dan tunjangan serta terjadi kenaikan dari gaji yang mereka terima, maka kinerja dari karyawan tersebut akan meningkat pula.

\section{PENUTUP}

\section{Simpulan}

Berdasarkan hasil penelitian dan pembahasan, maka dapat dibuat kesimpulan sebagai berikut:

1. Keadilan kompensasi tidak berpengaruh terhadap kinerja karyawan.

2. Kepuasan kompensasi berpengaruh signifikan terhadap kinerja karyawan.

3. Terdapat pengaruh secara bersamasama antara keadilan kompensasi dan kepuasan kompensasi terhadap kinerja karyawan.

\section{Rekomendasi}

Berdasarkan simpulan di atas, maka rekomendasi yang dapat diberikan adalah sebagai berikut:

1. Pemilik UMKM Pempek Palembang harus tetap mempertahankan bahkan meningkatkan tingkat gaji karyawannya sehingga karyawan akan terus merasa puas terhadap kompensasi yang diterima.

2. Untuk meningkatkan kinerja karyawan selain melalui pemberian kompensasi, para pemilik UMKM Pempek Palembang juga dapat memfasilitasi karyawannya untuk dapat mengikuti program-program pelatihan sehingga variabel pelatihan ini dapat ditambahkan untuk penelitian selanjutnya.

\section{DAFTAR PUSTAKA}

Dessler, G. (2017). Human Resource Management.

Fernanda, R., \& Sagoro, E. (2016a). Pengaruh Kompensasi, Kepuasan Kerja, Motivasi Kerja Dan Gaya 
Kepemimpinan Terhadap Kinerja Karyawan. Jurnal Nominal / Volume V Nomor 2 / Tahun 2016, V.

Fernanda, R., \& Sagoro, E. M. (2016b).

Pengaruh Kompensasi, Kepuasan Kerja, Motivasi Kerja Dan Gaya Kepemimpinan Terhadap Kinerja Karyawan. Jurnal Nominal, $V$.

Hasibuan, M. S. P. (2011). Manajemen Sumber Daya Manusia. Edisi Revisi Jakarta: Bumi Aksara.

Heri Setiawan. (2017). Rekomendasi Intervensi Ergonomi Pada Ukm Unggulan Provinsi Sumatera Selatan. Jurnal Logic Vol.17 No.2 Juli 2017, 17(2), 86-91.

Intan Retno Edy. (2013). Analisis Pengaruh Keadilan Distributif Kompensasi Dan Keadilan Prosedural Kompensasi Terhadap Kinerja Yang Dimediasi Oleh Kepuasan Kerja Pada Karyawan Di Rsud Kraton Kabupaten Pekalongan. Jbti, Iv(1), 120-138.

Ivancevich, J. M., Konopaske, R., \& Matteson, M. T. (2014). Organizational Behavior And Management. Professional Safety, 40(10), 36. Retrieved From Http://Search.Ebscohost.Com/Login.

Aspx?Direct $=$ True $\& D b=B$ th $\& A n=95$ $10242795 \&$ Site $=$ Ehost-Live

Jackson, S., Schuler, R., \& Werner, S. (2011). Managing Human Resources. Mangkunegara, A. A. A. P. (2003). Manajemen Sumber Daya Manusia Perusahaan. Remaja Rosdakarya. Https://Doi.Org/10.1038/Cddis.2011. 1

Mathis, R. L., \& Jackson, J. H. (2010a). Human Resource Management. Workforce (Vol. 46). Https://Doi.Org/10.1055/S-00301270560

Mathis, R. L., \& Jackson, J. H. (2010b).
Human Resource Management. Workforce (Vol. 46). Https://Doi.Org/10.1055/S-00301270560

Mondy, R. W., \& J. Martocchio. (2016). Human Resource Management.

Mondy R.W., M. J. J. (2016). Human Resource Management.

Muljanah, T. S. (2009). Prospek Pengembangan Usaha Pengolahan. Squalen Vol.4 No.1, Mei 2009, 4(1), 31-40.

Muljani, N., Pengajar, S., Ekonomi, F., Katolik, U., \& Surabaya, W. M. (2002). Kompensasi Sebagai Motivator Untuk Meningkatkan Kinerja Karyawan. Jurnal Manajemen \& Kewirausahaan Jurusan Ekonomi Manajemen, 4(2), 108-122.

Https://Doi.Org/10.9744/Jmk.4.2.Pp. 108-122

Nurfitriana, N., Fatchiya, A., \& Susanto, D. (2016). Perilaku Kewirausahaan Pelaku Usaha Pempek Skala Industri Kecil Dan Menengah Di Kota Palembang, Provinsi Sumatera Selatan. Jurnal Penyuluhan, September 2016 Vol. 12 No. 2, 12(2). Robbins, S. P., \& Judge, T. A. (2013). Organizational Behavior. Pearson Education Limited (Vol. 40). Https://Doi.Org/10.1017/Cbo9781107 415324.004

S. Pantja Djati, \& M. Khusaini M. Khusaini. (2003). Kajian Terhadap Kepuasan Kompensasi, Komitmen Organisasi, Dan Prestasi Kerja. Jurnal Manajemen Dan Kewirausahaan, 5, Pp.25-41. Retrieved From Http://Puslit2.Petra.Ac.Id/Ejournal/In dex.Php/Man/Article/View/15631

Sadzwina, R., \& Gilang, A. (2015). 
Pengaruh Kompensasi Terhadap Kinerja Karyawan ( Studi Pada Hotel Kartika Chandra Jakarta ). EProceeding Of Management Vol.2 No.1 April 2015, 671, 2(1), 671-685.

Siagian, S. S. I. (2015). Pengaruh Pelatihan, Kepuasan Kompensasi, Motivasi... -. Jurnal Ilmu Dan Riset Manajemen Volume 4, Nomor 9, Agustus 2015, 4, 1-20.

Tamma, F., \& Iskandar, D. (2015).

Pengaruh Kompensasi Finansial Terhadap Kinerja Karyawan ( Studi Kasus CV . Qitarabu Jaya Utama ). EProceeding of Management Vol.2
No.3 Desember 2015, 2496, 2(3), 2496-2502.

Welta, F. (2016). Analisis strategi pemasaran dalam peningkatan keunggulan bersaing sektor umkm di kota palembang 1. Seminar Nasional Teknologi Informasi, Bisnis, Dan Desain 2016, 6-9.

(http://www.palembang.go.id, 9 Agustus 2017).

(http://palembang.tribunnews.com/,, 11 April 2014). 